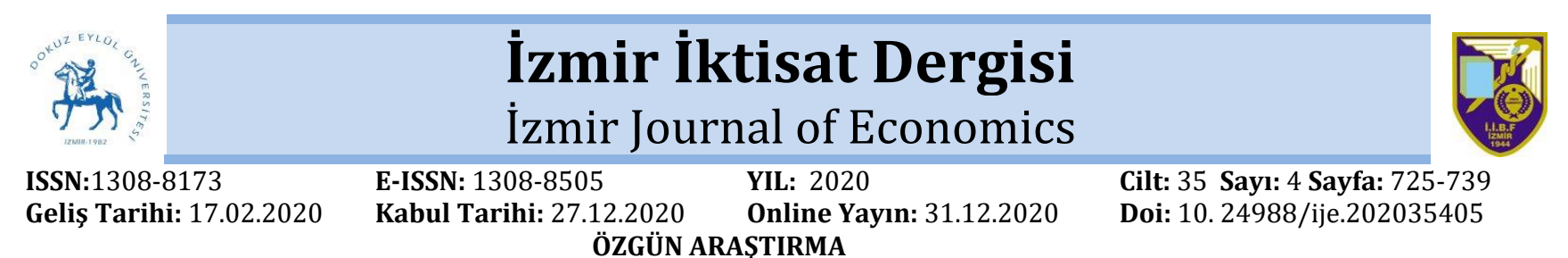

\title{
Doğrudan Yabancı Yatırımlar ve Beşerî Sermaye İlişkisi: BRICS-T Ülkeleri Üzerine Bir Uygulama*
}

\author{
Bilal ÇAYIR ${ }^{1}$, Ekrem ERDEM ${ }^{2}$ \\ Özet
}

Bu çalışmada, Lucas Paradoksu çerçevesinde BRICS-T ülkeleri özelinde beșerî sermayenin DYY girişleri üzerindeki etkisinin 1993-2017 dönemi için test edilmesi amaçlanmıştır. DYY girișlerinin geleneksel belirleyicileri olması bakımından ticarete açıklık, piyasa büyüklüğ̈̈, doğal kaynak zenginliği ve enflasyon oranı da modelde kullanılmıștır. Değisskenler arasında eşbütünleşme ilişsisinin tespitinden hareketle elde edilen uzun dönemli tahminci bulguları, BRICS-T ülkelerinde beşerî sermayenin DYY girişlerini pozitif yönde ve anlamlı bir șekilde etkilediğini göstermektedir. Diğer yandan doğal kaynak zenginliği ile DYY girişleri arasında pozitif, enflasyon oranı ve DYY girişleri arasında ise negatif yönlü ilişki tespit edilmiştir. Ticarete açıklık ve piyasa büyüklüğü değisskenleri kullanılan tahmincilere göre farklı sonuçlar ortaya koymuștur.

Anahtar kelimeler: Beșeri Sermaye, Doğrudan Yabancı Yatırımlar, Panel Veri Analizi, Lucas Paradoksu Jel Kodu: F21, F23, J24,

\section{Foreign Direct Investments and Human Capital Nexus: An Application on BRICS-T Countries}

\section{Abstract}

This paper aims to analyze the effect of human capital on FDI inflows within the framework of Lucas Paradox. Trade openness, market size, natural resource wealth and inflation rate which are intensively processed in the literature are used as explanatory variables in terms of being possible determinants of FDI inflows. The findings indicate that the human capital positively affects FDI inflows in BRICS-T countries. On the other hand, positive correlation is found between natural resource wealth and FDI inflows, while negative correlation is found between inflation rate and FDI inflows. Trade openness and market size have produced contradictory results.

Keywords: Human Capital, Foreign Direct Investment, Panel Data Analysis, Lucas Paradox, Jel Codes: F21, F23, J24,

\section{GíRIŞ}

II. Dünya Savaşı sonrasında teknolojik gelişmelerin etkisi ve üretim faaliyetlerinde yaşanan dönüşümler ülkeler arasında farklı rekabet alanları doğurmuştur. $\mathrm{Bu}$ süreçte birçok ülke bilgi ekonomisi temelinde beşerî sermaye düzeyi ve teknolojik gelişme seviyelerini artırma ve buna bağlı olarak ekonomik büyümeyi ve kalkınmayı sürekli hale getirme çabası içine girmiştir. Özellikle gelişmekte olan ülkeler söz konusu iktisadi faaliyetlerini sürdürmek isterken, diğer taraftan kaynak sıkıntısı çekme ve yetersiz tasarruf gibi sorunlarla karşı karşıya kalmaktadırlar. Bu bağlamda yabancı sermaye yatırımlarının ülkeye çekilerek üretimin, istihdamı ve ekonomik büyümenin gerçekleştirilmesi stratejik bir hedef olarak öne çıkmaktadır.

Çok uluslu şirketler tarafından gerçekleştirilen doğrudan yabancı yatırımların (DYY) ev sahibi

ATIF ÖNERİSi (APA): Çayır, B., Erdem, E. (2020). Doğrudan Yabancı Yatırımlar ve Beşeri Sermaye İlişkisi: BRICS-T Ülkeleri Üzerine Bir Uygulama. İzmir Journal of Economics, 35(4). Doi: 10. 24988/ije.202035405

* Bu çalışma Prof. Dr. Ekrem ERDEM danışmanlığında Erciyes Üniversitesi Sosyal Bilimler Enstitüsünde yürütülen “Doğrudan Yabancı Sermaye Girişlerinde Beşerî Sermayenin Önemi: BRICS-T Ülkeleri Üzerine Bir Uygulama" başlıklı yüksek lisans tezinden türetilmiștir.

${ }^{1}$ Arş. Gör, Hasan Kalyoncu Üniversitesi, İktisadi, İdari ve Sosyal Bilimler Fakültesi, GAZİANTEP,

EMAIL: bilalcayir2@gmail.com ORCID: 0000-0001-5340-6635

2 Prof. Dr., Erciyes Üniversitesi, İktisadi ve İdari Bilimler Fakültesi, KAYSERİ,

EMAIL: ekremerdem@erciyes.edu.tr ORCID: 0000-0002-5876-8747 


\section{B. CAYIR, E. ERDEM}

ülkelerde aradıkları belirli faktörler öne çıkmaktadır. Konuyla ilgili literatürde; DYY girişlerinde özellikle doğal kaynak zenginliği, ticarete açıklık düzeyi, piyasa büyüklügüu, altyapı düzeyi, enflasyon oranı, işgücü maliyetleri ve kurumsal kalite gibi faktörlerin önemli olduğu tespit edilmiştir. Ancak son dönemde ev sahibi ülkenin beșerî sermaye düzeyinin DYY girişleri üzerinde olumlu bir etkisi olacağına dair ileri sürülen görüş ilgi çekmektedir. Bu bağlamda Lucas (1990) tarafından ileri sürülen ve neoklasik iktisadi anlayıșa atfedilen sermayenin marjinal getirisi yaklaşımının pratikte çalışmadığını ifade eden yaklaşım farklı bir konuma sahiptir.

Lucas (1990), sermayenin marjinal getirisinin düşük olduğu gelişmiş ülkelerden, marjinal getirinin yüksek olduğu az gelişmiş ülkelere doğru hareket edeceğini ileri süren neoklasik iktisadi yaklaşımın pratikte beklenilen ölçüde çalışmadığını ifade etmiştir. Lucas Paradoksu olarak bilinen bu duruma sebep olarak ise, az gelişmiş ve gelişmiş ülkeler arasındaki beșerî sermaye düzeyindeki farklılıklar ve sermaye piyasasındaki aksaklıkları öne sürmüştür. Takip eden süreçte DYY girişlerinin geleneksel belirleyicileri olarak analizlere dahil edilen doğal kaynak zenginliği, altyapı, piyasa büyüklüğü gibi faktörlerin yanı sıra beșerî sermaye düzeyi de söz konusu analizlerde yer bulmaktadır.

Bu çalışmada, beşerî sermaye düzeyinin DYY girişleri üzerindeki etkisi 1993-2017 dönemine ait yıllık veriler kullanılarak BRICS (Brezilya, Rusya, Hindistan, Çin, Güney Afrika) ülkeleri ve Türkiye (BRICS-T) üzerinde analiz edilmiştir. UNCTAD (2018) raporuna göre, gelişmekte olan ülkeler dünya genelinde 2017 yılında DYY girişlerinin \%47'sine ev sahipliği yapmıştır. Yine 2017 yılı için BRICS ülkeleri ve Türkiye'nin bu oran içerisindeki payına bakıldığında ise, yaklaşık \%20 civarında DYY'nin BRICS-T ülkelerine giriş yaptığı görülmektedir. Şekil 1'de BRICS ülkeleri ve Türkiye'nin 2017 yılında dünya genelinde toplam DYY girişlerinden aldıkları pay gösterilmektedir.

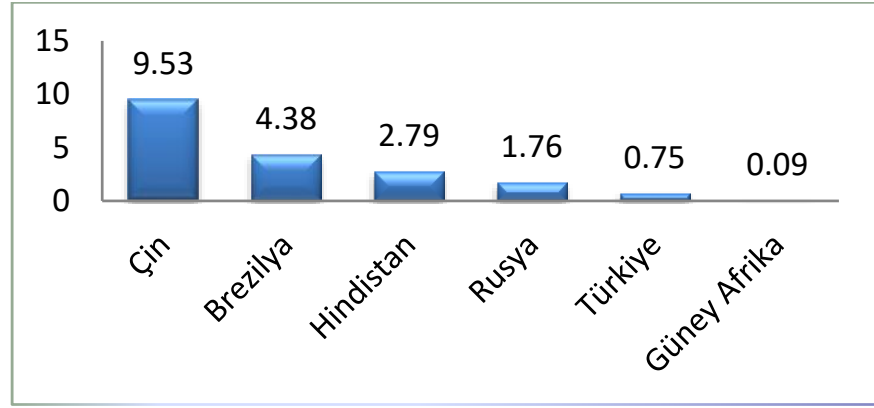

Şekil 1. BRICS-T Ülkelerinin Toplam DYY Miktarından Aldıkları Pay (\%)

Kaynak: UNCTADstat, Foreign Direct Investment: Inward and Outward Flows and Stock

Şekil 1'de görüldüğü üzere, Çin toplam DYY miktarı içerisinde \%9 civarında bir yatırımla açık ara daha fazla doğrudan yatırım çekmiştir. Öte yandan Brezilya ve Hindistan toplamda \% 7 civarında DYY girişine ev sahipliği yapmıştır. Rusya, Türkiye ve Güney Afrika ise diğer ülkelere kıyasla çok daha düşük miktarda doğrudan yatırım çekebilmiştir. Özellikle Türkiye ve Güney Afrika'nın grup içerisindeki diğer ülkelerin çok uzağında kaldıkları görülmektedir.

Çalıșmanın temel amacı, yakın gelecekte dünya ekonomisine yön vermesi beklenen BRICS-T ülkeleri için beşerî sermayenin DYY girişleri üzerindeki etkisini analiz etmektir. $\mathrm{Bu}$ anlamda, BRICS-T ülkelerinin sahip olduğu beşerî sermaye düzeyinin DYY girişleri üzerinde pozitif yönlü bir etkisi olacağ beklenmektedir. Çalışmada panel veri yöntemi kullanılmış ve panel birim kök testleri, panel eş bütünleşme testleri ile Panel FMOLS (Tam Düzeltilmiş En Küçük Kareler) ve DOLS (Dinamik En Küçük Kareler) tahmincilerinden elde edilen sonuçlardan hareketle bir analiz yapılmıştır. Yapılan ekonometrik analizde, DYY girişlerinin belirleyicileri olarak literatürde sıklıkla kullanılan ticarete açıklık, piyasa büyüklüğü, doğal kaynak zenginliği ve enflasyon oranı da modelde yerini almıştır.

\section{LITTERATÜR İNCELEMESİ}

Giriş bölümünde bahsedildiği üzere, beșerî sermaye ve yabancı sermaye yatırımları arasındaki ilişki için Lucas'ın yaklaşımı önemli bir yer tutmaktadır. Lucas, 1990 yılında 
yayınladığı çalışmada, ABD ve Hindistan arasındaki sermaye akımlarını incelemiştir. Hindistan'da sermayenin marjinal ürününün ABD'ye kıyasla 58 kat daha fazla olmasina rağmen, yabancı yatırımların ABD'de yoğunlaştığını gözlemlemiştir. Lucas, CobbDouglas üretim fonksiyonunu kullanarak gerçekleştirdiği analize işçi başına beșerî sermaye değişkenini eklediğinde iki ülke arasındaki sermayenin marjinal ürünü arasındaki farkın ciddi ölçüde azaldığı sonucuna ulaşmıştır. Dolayısıyla Lucas, emek faktörünün dolașımının pek de mümkün olmadı̆̆ı günümüzde beşerî sermaye düzeyini yükseltecek politikalara ihtiyaç duyulduğunu ifade etmiştir. Bu kapsamda, çalışmada Lucas'ın analizinin yanında yabancı sermaye girişlerinin bir belirleyicisi olarak beșerî sermayeyi analiz eden çalışmalar da incelenmiştir. Bahsedilen analizler 1980 öncesi verilerle yapılan analizler ve 1980 sonrası verilerin kullanıldığı analizler olarak farklı sonuçlar ortaya koymaktadır. Birinci grup olarak ifade edilen 1960-1980 yıllarına ait veri setlerine dayanan analizler Root ve Ahmed (1979), Scneider ve Frey (1985), Hanson (1996) ve Narula (1996) tarafından yapılmıştır.

Root ve Ahmed (1979), 58 adet gelişmekte olan ülke üzerinde yaptıkları analizde okur-yazarlık, eğitime katılma ve nitelikli işgücü gibi değişkenlerle ifade edilen beşerî sermaye faktörünün doğrudan yatırım girişlerinde istatistiksel olarak anlamının olmadığı sonucuna ulaşmışlardır. Scneider ve Frey (1985) ise, 54 adet gelişmekte olan ülke verilerini kullanarak yaptıkları analizde ortaöğretim düzeyinde eğitime sahip olan yaş grubunun diğer ekonomik ve politik faktörlerine nazaran doğrudan yatırım girişlerinde çok daha az etkili olduğunu ortaya koymuşlardır. Öte yandan Hanson (1996) 105 adet gelişmekte olan ülkenin dâhil ettiği analizinde; yetişkin okur-yazarlık oranının diğer faktörlerle karşılaștırıldığında önemli bir değişken olmadığı sonucunu elde etmiştir. Bahsi geçen bu analizlerde teorik literatürün aksine beşerî sermaye göstergelerinin doğrudan yatırım üzerinde etkisinin olmadığı görülmektedir. Narula (1996) ise, 22 adet gelişmekte olan ülkenin dahil olduğu çalışmasında toplam nüfus içerisinde yükseköğrenime sahip olan birey sayısının anlamlı bir değişken olmadığı sonucuna ulaşmıştır.

Buna göre, analizlerin dayandığı 1960-1980 arası dönemde yabancı yatırımcıların doğrudan yatırımlarını ülkelerin beșerî sermaye düzeylerinden ziyade piyasa büyüklüğü ve kaynak bakımından zengin olma kriterlerine bakarak gerçekleştirdiklerini göstermektedir (Miyamoto, 2003: 22).

1980 sonrası döneme ait verilerle gerçekleştirilen analizler ise teorik literatürde öngörülen yaklaşımı destekler niteliktedir. Nitekim, bu bağlamda bir çalışma olarak Coughlin ve Segev (2000), Çin'in 29 şehrine ait verileri kullanarak Çin'de DYY'nin coğrafi dağılımını incelemişlerdir. Yazarlar bu analizde En Küçük Kareler Yöntemine (EKK) dayanan regresyon analizi ve Mekânsal Ekonometrik Analiz olmak üzere iki farklı model test etmişlerdir. Elde edilen regresyon sonuçlarına göre, şehrin ekonomik büyüklügü ve sahile sahip olmasının, DYY girișlerini pozitif yönde etkilediği tespit edilmiştir. Analizdeki bulgular okur-yazarlık oranındaki yetersizliklerin DYY girişlerini olumsuz yönde etkilediğini ortaya koymuştur. Standart regresyon analizlerinde coğrafi verilerin mekânsal yapısının ölçülemiyor olması nedeniyle çalışmada ayrıca mekânsal bağımlılık ve farklılıklar mekânsal ekonometrik analiz yöntemiyle analiz edilmiştir. Elde edilen bulgulara göre, analize dâhil edilen bir şehre gelen doğrudan yatırımların artması çevre iller için olumlu yönde etki yapmaktadır. Ayrıca söz konusu 29 şehir için mekânsal farklılık tespit edilmemiştir.

Noorbakhsh, Paloni ve Youssef (2001), gelişmekte olan 36 ülke için doğrudan yatırımların ülkeye çekilmesinde beşerî sermayenin önemini analiz etmişlerdir. Elde edilen bulgulara göre, eğitim göstergelerinin kullanıldığı beşerî sermaye düzeyi, doğrudan yatırımlar üzerinde son derece açık ve 


\section{B. ÇAYIR, E. ERDEM}

istatistiksel olarak anlamlı bir etkiye sahiptir. Ayrıca yerel piyasaların büyüklügü, finansal serbestleşme politikaları, enerjiye ulaşım gibi değişkenlerin de doğrudan yatırım girişleri üzerinde olumlu ve anlamlı etkiye sahip olduğu görülmüştür. Ancak doğal kaynaklara ulaşım ve siyasi haklar endeksinin anlamlı sonuçlar vermediği gözlenmiştir.

Nunnenkamp (2002), gelişmekte olan 28 ülke üzerinde gerçekleştirdiği korelasyon analizi ile, 1987-1999 döneminde eğitime ayrılan sürenin DYY girişlerinin belirleyicisi olabileceği önermesini test etmiştir. Yazar, yabancı yatırımcıların ülkeye çekilmesinde geleneksel belirleyicilerin önemini korumakta olduğunu belirtirken, diğer yandan eğitime ayrılan süre gibi nitelikli işgücünü destekleyecek faktörlerin de önemini artırdığını ifade etmiştir. Yapılan korelasyon analizlerinde, eğitime ayrılan sürenin 1999 yılı sonuçlarına göre daha yüksek katsayıya sahip olduğu gözlemlenmiştir.

Checchi; De Simone ve Faini (2007), 67 ülke verilerini kullanarak yaptıkları analizde üç farklı eğitim düzeyinin (ilk, orta-lise ve yükseköğretime katılma) DYY girişleri üzerindeki etkilerini test etmişlerdir. Analizde 1990-2000 dönemine ait veriler kullanılmış ve panel EKK yöntemi, sabit etkiler modeli ve Hausman-Taylor testi uygulanmıştır. Elde edilen bulgulara göre, orta-lise öğreniminin DYY girişleri üzerinde pozitif yönlü ve anlamlı bir etkisi olduğu gözlemlenmiştir. Öte yandan, ilk ve yükseköğrenimin ise DYY girişleri üzerinde anlamlı bir etkisi olmadığı sonucuna ulaşılmıştır.

Mina (2007), 1980-2002 dönemine ait yıllık verilerden hareketle, Körfez İş Birliği Ülkeleri (Bahreyn, Kuveyt, Umman, Katar, Suudi Arabistan ve Birleşik Arap Emirlikleri) üzerinde DYY girişlerinin yerel belirleyicilerini test etmiştir. Sabit-Rastsal etkiler ve Hausman Testi tekniklerinin kullanıldığı analizde, Körfez İş Birliği Ülkeleri için Lucas paradoksunun aksine sonuçlar elde edilmiştir. Elde edilen bulgulara göre, Körfez İş Birliği Ülkeleri özelinde, beşerî sermaye düzeyinin DYY girişlerini olumsuz yönde etkilediği sonucuna ulaşılmıştır.

Majeed ve Ahmad (2008), 1970-2004 dönemine ait verilerden yola çlkarak gelişmekte olan 23 ülke üzerinde, beșerî sermaye gelişiminin DYY girişleri üzerindeki etkisini test etmişlerdir. Analizde beșerî sermaye göstergeleri olarak sağlık harcamaları ve okuma-yazma bilmeyenlerin oranı kullanılmıştır. Sabit etkiler modelinin kullanıldığı analizde, sağlık harcamalarının DYY girişleri üzerinde pozitif yönlü ve istatistiksel olarak anlamlı bir etkisinin olduğu gözlemlenmiştir. Okuma-yazma bilmeyenlerin oranı ise, beklentilerle uyumlu olarak DYY girişleri üzerinde negatif bir etki göstermiş ancak katsayısı istatistiksel olarak anlamlı bulunamamıştır.

Suliman ve Mollick (2009), 1980-2003 dönemi için 29 Sahra Altı Afrika ülkesi üzerinde yaptıkları çalışmada DYY' ye etkileri bakımından beşerî sermaye gelişimi ve savaş ortamı faktörlerini analiz etmişlerdir. Literatürde dikkate alınan diğer değişkenler olarak piyasa büyüklüğünü gösteren kişi başına milli gelir, ticarete açıklık, yarı-likit yükümlülükler, telefon hatları sayısı ve DYY gecikmeleri de modele dahil edilmiştir. Modelde savaşın doğrudan yatırımlara etkisini test edebilmek için "WAR" adında KUKLA değişken oluşturulmuştur. Analiz için kullanılan model panel veri analizi dahilinde sabit etkiler modeli olarak belirlenmiştir. Elde edilen bulgulara göre, okur-yazarlık oranı, siyasi-sivil haklar ve siyasi karıșıklıklar ve çatışma DYY'nin belirleyicileri olarak tutarlı ve anlamlı sonuçlar vermiştir. Okur-yazarlık oranı ve siyasi-sivil haklar ile DYY arasında pozitif yönlü ilişki tespit edilmiştir. Ayrıca savaş ve kargaşa olaylarının DYY girişleri üzerinde olumsuz etkisi gözlemlenmiştir.

Bal; Algan ve Demiral (2014), tarafından yapılan araştırmada Balkan bölgesinde bulunan 9 ülke için (Arnavutluk, Bosna-Hersek, Bulgaristan, Hirvatistan, Yunanistan, Romanya, Slovenya, Makedonya, Türkiye) Lucas Paradoksu çerçevesinde doğrudan yatırım 
girişlerinin belirleyicileri analiz edilmiştir. Araștırmada 2000-2012 arası döneme ait veri seti kullanılmıștır. Kişi başına reel fiziki sermaye stoku ile DYY girişi arasında pozitif ve anlaml, beşerî sermaye stoku ve DYY arasında pozitif ve anlamlı ve açıklık, Ar-Ge harcamaları ile DYY arasında anlamlı sonuçlara ulaşılmıştır. Dolayısıyla ele alınan dönem içerisinde Lucas paradoksunu destekleyen bulgular elde edilmiştir. Öte yandan ülke riski, ticaret engelleri ve korumacılık değişkenleri DYY ile ilişkileri bakımından negatif ve anlamlı sonuçlar ortaya koymuştur. Son olarak, piyasa hacmi, emek maliyeti, fiyat düzeyi, doğal kaynak zenginliği ve döviz kuru gibi değişkenler Balkan ülkelerinde DYY girişlerinin belirleyicileri olarak anlaml sonuçlar vermemiştir.

Cleeve; Debrah ve Yıheyis (2015), beșerî sermayenin doğrudan yatırımlar üzerindeki etkisini 1980-2012 dönemine ait verilerle 35 Sahra-Altı Afrika ülkesi için panel veri yöntemiyle sınamışlardır. Bağımlı değişken olarak DYY girişlerinin GSYH içerisindeki payı kullanılırken, bağımsız değişkenler olarak beşerî sermaye göstergelerinin yanı sıra piyasa büyüklüğü, politik, kurumsal, ticarete açlklık, altyapı, sahile ulaşım, enflasyon oranı ve doğal kaynaklar gibi göstergeler de modelde kullanılmıştır. Okur-yazarlık oranı ve orta ve yükseköğretime kayıt oranı gibi göstergelerden oluşan beşerî sermaye faktörünün DYY girişleri üzerinde pozitif ve anlaml etkiye sahip olduğu görülmüştür. Ayrıca kontrol değişkenleri olarak adlandırılan piyasa büyüklüğü, doğal kaynak zenginliği ve büyük küresel ekonomik krizlerin DYY girişlerini anlamlı bir şekilde etkilediği gözlemlenmiştir.

Kumari ve Sharma (2017), Güney, Doğu ve Güneydoğu Asya'da bulunan 20 gelişmekte olan ülke için 1990-2012 yıllarına ait verilerle DYY girişlerinin belirleyicilerini analiz etmişlerdir. Çalışmada panel EKK (Sabit ve Rassal etkiler) metodu ve sonrasinda uygun modelin seçilebilmesi için Hausman testi uygulanmıștır. Modelde bağımsız değişken olarak DYY girişleri, açıklayıcı değişkenler için ise beșerî sermaye, piyasa büyüklügü, ticarete açıklık, altyapı, enflasyon, reel faiz oranı ve ArGe kullanılmıştır. Bulgulara göre, beșerî sermaye ve piyasa büyüklügü ile DYY girişleri arasında pozitif yönlü ilişki tespit edilmiştir. Öte yandan altyapı ve enflasyon değişkenleri ile DYY girişleri arasında negatif ve anlaml sonuçlara ulaşılmıştır. Ticarete açıklık ve Ar-Ge ile DYY arasında istatistiksel olarak anlamsız sonuçlar elde edilmiştir. Son olarak beșerî sermaye ile DYY girişleri arasında pozitif ve anlamlı sonuçlara ulaşılmıştır. Regresyon bulguları beșerî sermaye faktöründeki \%1'lik artışın DYY girişlerini \%0.003 artırdığını ortaya koymuştur.

Zhuang (2017), Doğu Asya ülkeleri üzerine yaptığı çalışmada DYY'nin farklı tiplerde beșerî sermaye göstergeleri üzerindeki etkisini incelemiştir. Özetlenen diğer çalışmaların aksine bu analizde DYY girişlerinin beşerî sermaye faktörüne katkıları ortaya konmuştur. 16 Doğu Asya ülkesine ait 1985-2010 yıllarını kapsayan verilerin kullanıldığı çalışmada panel veri yöntemi uygulanmıştır. Elde edilen bulgulara göre, DYY girişlerinin Doğu Asya ülkelerinin yükseköğrenimi üzerinde negatif yönlü etkisi olduğu gözlemlenmiştir. Öte yandan, ortaöğretim üzerinde ise pozitif yönlü ve anlamlı ilişkinin olduğu sonucuna ulaşılmıştır.

Sonuç olarak 1980 sonrası verilere dayanarak yapılan mevcut çalışmalar ele alınan farklı ülke ve bölgeler itibariyle beșerî sermaye faktörünün DYY girişlerinin anlamlı bir belirleyicisi olduğunu ortaya koymaktadır. Dolayısıyla söz konusu analiz sonuçlarının Lucas paradoksunu destekleyici nitelikte olduklarını söylemek mümkündür.

\section{MODEL VE VERİ SETİ}

Çalışmanın bu bölümünde, BRICS-T ülkeleri açısından beşerî sermaye faktörünün DYY girişleri üzerindeki önemi test edilmiştir. Ayrıca diğer belirleyici faktörler olan piyasa büyüklüğü, ticari açıklık düzeyi, doğal kaynak zenginliği ve enflasyon oranı da modele dâhil edilmiştir. Panel veri yönteminin kullanıldığı çalışmada 1993-2017 


\section{B. CAYIR, E. ERDEM}

dönemine ait yıllık verilerden yola çıkılarak panel birim kök testleri, panel eş bütünleşme testleri, Panel FMOLS ve Panel DOLS gibi tahminci sonuçlarına yer verilmiştir. Panel veri analizlerinde dikkate alınması gereken bazı öncü analizler, yatay kesit bağımlılığının ve ülke bazlı katsayıların homojenliğinin test edilmesidir. Katsayıların homejenliğini test etmek amacıyla literatürde sıklıkla kullanılan testlerden birisi, Peseran ve Yamagata (2008) tarafından geliştirilen Delta $(\tilde{\Delta})$ testidir. Delta testi yardımıyla boş hipotez olan katsayı homojenliği, katsayıların heterojen olduğunu ileri süren alternatif hipoteze karşı sınanmaktadır. Yatay kesit bağımlıı̆̆ı testleriyle ise, panele dahil edilen birimlerden herhangi birinde meydana gelen şokun diğer birimler üzerinde etkisi olup olmadığı test edilmektedir. Bu kapsamda Breusch ve Pagan (1980) tarafından geliştirilen LM testi, Peseran (2004) CDLM ve CD testi ve Peseran vd. (2008) tarafından geliştirlen $\mathrm{LM}_{\text {adj }}$ testi panel veri analizlerinde sıklıkla kullanılmaktadır. Modelde yer alan değişkenlerin birim kök içerip içermediklerini test edebilmek amacıyla birinci nesil birim kök testlerinden Levin, Lin Chu (LLC), Im, Peseran, Shin (IPS) ve Fisher ADF panel birim kök testleri kullanılmıştır. Ancak birinci nesil birim kök testlerinin yatay kesit bağımlılı̆ını dikkate almaması nedeniyle, Peseran (2007) tarafından geliştirilen, yatay kesit bağımlılığını ve katsayı heterojenliğini dikkate alan CADF panel birim kök testi analize dahil edilmiştir. CADF tekniği esasen, standart ADF regresyonlarının genişletilmiş bir versiyonundan hareketle, yatay kesit ortalamalarının kullanılmasını öneren bir panel birim kök testidir (Peseran, 2007:302). Akabinde değişkenler arasındaki uzun dönemli ilişkinin mevcudiyetini test edebilmek amacıyla yatay kesit bağımlılığının dikkate alındığı ve Westerlund (2008) tarafından geliştirilen Durbin-H panel eşbütünleşme testi uygulanmıştır. Grup istatistikleri ve panel istatistikleri olmak üzere iki farklı testten oluşan Durbin-H testi yatay kesit bağımlılığını da dikkate alması bakımından çalışmada tercih edilmiştir. Durbin-H panel eşbütünleşme testinde eşbütünleşme olmadığını ifade eden boş hipotez, eşbütünleşme ilişkisinin varlığını savunan alternatif hipoteze karşı sınanmaktadır. Eşbütünleşme ilişkisine dair yorumları güçlendirebilmek amacıyla çalışmada ayrıca Pedroni ve Kao panel eşbütünleşme testleri de çalıştırılmıştır. Son olarak, uzun dönemli tahminciler olarak bilinen panel FMOLS ve panel DOLS tahminci sonuçlarına yer verilmiştir. Analizde kullanılan model şu şekildedir:

$\ln F D I_{i t}=\beta_{0 i}+\beta_{1 i} \ln H C_{i t}+\beta_{2 i} \ln G D P_{i t}+$ $\beta_{3 i} \operatorname{lnOPEN} N_{i t}+\beta_{4 i} \ln N R_{i t}+\beta_{5 i} \operatorname{lnINF_{it}}+\varepsilon_{i t}$

Yukarıda verilen modele göre, FDI değişkeni DYY girişlerini, HC beşerî sermayeyi, GDP kişi başına milli geliri, OPEN ticari açıklık düzeyini, NR doğal kaynak zenginliğini ve son olarak INF ise, enflasyon oranını ifade etmektedir. Bu çalışmada değişkenlerin tümü logaritmik dönüşümleri yapılarak analiz edilmiştir. Tablo 1'de modelde kullanılan değişkenlerin kısaltmaları, elde edildikleri kaynaklar ve açıklayıcı değişkenlerin bağımlı değişken üzerindeki beklenen etkisi gösterilmektedir.

Tablo 1: Analizde Kullanılan Değişkenlere Dair Bilgiler

\begin{tabular}{|c|c|c|c|}
\hline Değişkenler & Tanımı & Kaynak & $\begin{array}{l}\text { İlişkinin } \\
\text { Beklenen } \\
\text { Yönü }\end{array}$ \\
\hline $\begin{array}{l}\text { lnFDI } \\
\text { (Bağımlı } \\
\text { Değișken) }\end{array}$ & $\begin{array}{l}\text { Net DYY girişleri } \\
\text { (GSYİH \% payı) }\end{array}$ & $\begin{array}{c}\text { World } \\
\text { Bank } \\
\text { Data }\end{array}$ & \\
\hline $\ln \mathrm{HC}$ & $\begin{array}{c}\text { İnsani Kalkınma } \\
\text { Endeksi (Eğitim- } \\
\text { Sağlık) }\end{array}$ & UNDP & Pozitif \\
\hline $\operatorname{lnGDP}$ & $\begin{array}{c}\text { Kişi Başına Milli } \\
\text { Gelir (2010 Sabit } \\
\text { ABD Doları) }\end{array}$ & $\begin{array}{c}\text { World } \\
\text { Bank } \\
\text { Data }\end{array}$ & Pozitif \\
\hline InOPEN & $\begin{array}{c}\text { Mal ve Hizmet } \\
\text { İhracatının GSYİH } \\
\text { içindeki \% payı }\end{array}$ & $\begin{array}{c}\text { World } \\
\text { Bank } \\
\text { Data }\end{array}$ & Pozitif \\
\hline $\operatorname{lnNR}$ & $\begin{array}{c}\text { Toplam Doğal } \\
\text { Kaynak } \\
\text { Kiralamaları } \\
\text { (GSYİH içindeki \% } \\
\text { payı) }\end{array}$ & $\begin{array}{l}\text { World } \\
\text { Bank } \\
\text { Data }\end{array}$ & Pozitif \\
\hline $\operatorname{lnINF}$ & $\begin{array}{l}\text { Enflasyon Oranı } \\
\text { (TÜFE) }\end{array}$ & $\begin{array}{c}\text { World } \\
\text { Bank } \\
\text { Data }\end{array}$ & Negatif \\
\hline
\end{tabular}


Modelde kullanılan değișkenler 1993-2017 dönemine ait yıllık veriler aracılığıyla analiz edilmiştir. Birleşmiş Milletler Kalkınma Programı (UNDP) tarafından yayınlanan insani gelişme endeksi, gerek eğitim gerekse sağlık göstergelerini bünyesinde barınması nedeniyle kapsamlı bir beșeri sermaye göstergesi olarak modelde yer almıştır. Öte yandan, bağımlı değişkeni ifade eden net DYY girişleri ve diğer açılkayıcı değişkenlere ait veriler Dünya Bankası veri tabanından elde edilmiştir. DYY girişleri ile enflasyon oranı dışındaki tüm açıklayıcı değişkenler arasında pozitif yönlü bir ilişki öngörülmektedir.

\section{UYGULAMANIN BULGULARI}

Uygulama bölümünde öncelikle, kullanılacak olan ekonometrik tekniklerin belirlenebilmesi için panele dahil edilen birimler arasında korelasyonun varlığı tespit edilmektedir. $\mathrm{Bu}$ bağlamda, Tablo 2'de yatay kesit bağımlılığı testi sonuçlarına yer verilmiştir.

Tablo 2: Yatay Kesit Bağımlılığı ve Delta Testleri

\begin{tabular}{|c|c|c|}
\hline Test & İstatistik Değeri & Olasılık Değeri \\
\hline \multicolumn{3}{|c|}{ Birimler Arası Korelasyon Testleri } \\
\hline LM & 106.717 & 0.000 \\
\hline $\mathrm{CD}_{\mathrm{LM}}$ & 16.745 & 0.000 \\
\hline $\mathrm{CD}$ & -0.232 & 0.408 \\
\hline$L_{\text {adj }}$ & 1.503 & 0.066 \\
\hline \multicolumn{3}{|c|}{ Delta Testleri } \\
\hline$\tilde{\Delta}$ & 6.127 & 0.000 \\
\hline$\tilde{\Delta}_{\text {adj }}$ & 7.168 & 0.000 \\
\hline
\end{tabular}

Tablo 2'de yer alan bulgulara göre LM ve $C_{\mathrm{LM}}$ testi bulguları, "yatay kesit bağımlılığı yoktur" boş hipotezini \%1 anlam düzeyinde ret etmektedir. LMadj testine ait bulgu ise \%10 anlam düzeyinde yatay kesit bağımlılığının varlığını teyit etmektedir. $\mathrm{Bu}$ bulgulardan hareketle, BRICS-T ülkelerinden birinde yaşanabilecek olan bir şokun panele dahil edilen diğer ülkeleri de etkileyebileceği ifade edilebilir. Diğer yandan Tablo 2 aynı zamanda katsayı homojenliğini sinayan Delta testi sonuçlarını da ortaya koymaktadır. Buna göre, katsayı homojenliği testleri \%1 anlam düzeyinde boș hipotezi ret ederek, panele dahil edilen birimlerin katsayılarının heterojen olduğunu ortaya koymuştur.

Elde edilen ön bulgular, yatay kesti bağımlılığı ve katsayı heterojenliğini dikkate alan birim kök testinin gerekliliğini ortaya koymaktadır. Bu kapsamda, Tablo 3'te CADF panel birim kök testi bulgularına yer verilmiştir.

Tablo 3: CADF Birim Kök Testi

\begin{tabular}{|c|c|c|c|c|}
\hline Değişkenler & $\begin{array}{c}\text { CADF- } \\
\text { stat } \\
\text { (Düzey) }\end{array}$ & $\begin{array}{c}\text { CADF- } \\
\text { stat }(\boldsymbol{\Delta})\end{array}$ & $\begin{array}{c}\text { CIPS-stat } \\
\text { (Düzey) }\end{array}$ & $\begin{array}{c}\text { CIPS-stat } \\
\mathbf{( \Delta )}\end{array}$ \\
\hline FDI & -2.148 & $-3.674^{*}$ & $-2.651^{*}$ & $-5.125^{*}$ \\
\hline HC & -1.441 & $-2.869^{*}$ & -2.036 & $-5.388^{*}$ \\
\hline LNGDP & -1.623 & $-2.648^{*}$ & -1.866 & $-3.464^{*}$ \\
\hline INF & $-3.884^{*}$ & $-4.502^{*}$ & $-3.531^{*}$ & $-5.003^{*}$ \\
\hline OPEN & $-2.613^{*}$ & $-2.967^{*}$ & $-3.188^{*}$ & $-3.790^{*}$ \\
\hline NR & -1.776 & $-3.534^{*}$ & -1.541 & $-4.128^{*}$ \\
\hline
\end{tabular}

Not: $\% 1, \% 5$ ve $\% 10$ düzeylerinde kritik değerler sırasıyla $-2.57,-2.33$ ve -2.21 'dir. * simgesi $\% 1$ anlam düzeyini ifade etmektedir.

Yatay kesit bağımlılığı ve katsayı heterojenliğinin dikkate alındığı durumda, CADF birim kök testi bulgularına göre, enflasyon ve ticari açıklık değişkenlerinin düzeyde durağan, modelde yer alan diğer tüm değişkenlerin ise birim kök içerdikleri görülmektedir. Diğer yandan, CIPS istatistiklerine ait bulgular CADF bulgularına ek olarak DYY değişkeninin düzeyde durağan olduğunu göstermektedir. Ancak hem CADF hem de CIPS istatistikleri tüm değişkenlerin birinci farkları alındığında durağan hale geldiğini göstermektedir.

Sahte regresyon probleminden kurtulabilmek ve bulguları desteklemek amacıyla ayrıca birinci nesil panel birim kök testlerine ait bulgulara da yer verilmektedir. Modelde yer alan bağımlı değişken ve açıklayıcı değişkenler için, öncelikle düzey değerleri itibariyle LLC (2002), IPS (2003) ve Fisher ADF (1999) panel birim kök testleri uygulanmıștır. Levin, Lin ve Chu (2002) tarafından geliștirilen LLC testinin temel varsayımı tüm birimlerin aynı otoregresif 


\section{B. ÇAYIR, E. ERDEM}

parametreye (p) sahip olduğudur. Im, Peseran ve Shin (2003) ise, heterojen panellerde birim kök hipotezini sinamak amaciyla IPS panel birim kök testini geliştirmişlerdir. Esasen bu test, bireysel birim kök testlerine dayanan temel bir t-bar istatistiği ortaya koymaktadır.
Son olarak Maddala ve Wu (1999), ADF temelli bir panel birim kök testi geliştirmişlerdir. Fisher testini temel alan bu modelin Levin, Lin ve IPS testlerine kıyasla daha basit ve düzgün bir işleyişe sahip olduğu ifade edilmektedir (Maddala ve Wu, 1999:650)

Tablo 4: Panel Birim Kök Testi Sonuçları (Seviye)

\begin{tabular}{|c|c|c|c|c|c|c|}
\hline \multirow[t]{2}{*}{ Değişkenler } & \multicolumn{2}{|c|}{ LLC } & \multicolumn{2}{|c|}{ IPS } & \multicolumn{2}{|c|}{ Fisher ADF } \\
\hline & Sabit & Sabit+ Trend & Sabit & Sabit+ Trend & Sabit & Sabit + Trend \\
\hline $\operatorname{lnFDI}$ & $\begin{array}{l}0.14977 \\
(0.5595)\end{array}$ & $\begin{array}{l}2.11606 \\
(0.9828)\end{array}$ & $\begin{array}{l}-2.04574^{* *} \\
(0.0204)\end{array}$ & $\begin{array}{l}-0.52241 \\
(0.3007)\end{array}$ & $\begin{array}{l}27.8751^{* * *} \\
(0.0058)\end{array}$ & $\begin{array}{l}14.2084 \\
(0.2876)\end{array}$ \\
\hline $\ln H C$ & $\begin{array}{l}-2.03874^{* *} \\
(0.0207)\end{array}$ & $\begin{array}{l}2.32924 \\
(0.9901)\end{array}$ & $\begin{array}{l}1.08245 \\
(0.8605)\end{array}$ & $\begin{array}{l}1.71515 \\
(0.9568\end{array}$ & $\begin{array}{l}8.18532 \\
(0.7705)\end{array}$ & $\begin{array}{l}7.45337 \\
(0.8263)\end{array}$ \\
\hline $\operatorname{lnGDP}$ & $\begin{array}{l}0.34000 \\
(0.6331)\end{array}$ & $\begin{array}{l}0.42815 \\
(0.6657)\end{array}$ & $\begin{array}{l}3.61354 \\
(0.9998)\end{array}$ & $\begin{array}{l}-0.67295 \\
(0.2505)\end{array}$ & $\begin{array}{l}2.23336 \\
(0.9990)\end{array}$ & $\begin{array}{l}13.8176 \\
(0.3125)\end{array}$ \\
\hline lnOPEN & $\begin{array}{l}-2.22412^{* *} \\
(0.0131)\end{array}$ & $\begin{array}{l}0.44381 \\
(0.6714)\end{array}$ & $\begin{array}{l}-2.46454^{* * *} \\
(0.0069)\end{array}$ & $\begin{array}{l}-0.34832 \\
(0.3638)\end{array}$ & $\begin{array}{l}26.6590^{* * *} \\
(0.0086)\end{array}$ & $\begin{array}{l}18.4291 \\
(0.1033)\end{array}$ \\
\hline $\operatorname{lnNR}$ & $\begin{array}{l}-0.70855 \\
(0.2393)\end{array}$ & $\begin{array}{l}0.32700 \\
(0.6282)\end{array}$ & $\begin{array}{l}-0.43528 \\
(0.3317)\end{array}$ & $\begin{array}{l}1.33738 \\
(0.9095)\end{array}$ & $\begin{array}{l}10.6834 \\
(0.5562)\end{array}$ & $\begin{array}{l}4.66876 \\
(0.9681)\end{array}$ \\
\hline $\operatorname{lnINF}$ & $\begin{array}{l}-2.77698^{* * *} \\
(0.0027)\end{array}$ & $\begin{array}{l}-2.05072^{* *} \\
(0.0201)\end{array}$ & $\begin{array}{l}-3.30083^{* * *} \\
(0.0005)\end{array}$ & $\begin{array}{l}-1.52222 \\
(0.0640)\end{array}$ & $\begin{array}{l}32.8823^{* * *} \\
(0.0010)\end{array}$ & $\begin{array}{l}19.3651 \\
(0.0801)\end{array}$ \\
\hline
\end{tabular}

Notlar: Parantez içindeki değerler olasılık değerlerini göstermektedir. ${ }^{* *} \% 5$ anlam düzeyini, ${ }^{* * *} \% 1$ anlam düzeyini ifade etmektedir. Gecikme uzunlukları Schwarz bilgi kriteri yardımıyla belirlenmiştir.

Tablo 4'de farkları alınmamıs ve düzey değerlerini ifade eden panel birim kök test sonuçlarına yer verilmektedir. Uygulanan üç panel birim kök testinde genel sonuçlara bakıldığında; olasılık değerlerinin \%5'ten büyük olduğu, diğer bir ifadeyle birim kök içerdikleri gözlemlenmektedir. Sabit ve sabit artı trend spesifikasyonlarının birlikte yer aldığı test sonuçlarına göre bağımlı değişken olan lnFDI için düzey değeri itibariyle boş hipotez reddedilememiş ve serinin birim kök içerdiği sonucuna ulaşılmıştır. Modelde açıklayıcı değişken olarak yer alan lnHC, lnGDP, lnOPEN, lnNR, lnINF isimli değişkenler için de boş hipotezin reddedilemediği, serilerin birim kök içerdiği görülmektedir. Dolayısıyla, analizde kullanılan üç panel birim kök testi sonuçlarına göre seriler düzey değerleri itibariyle birim kök içermektedir. Bu durumda modele dahil edilen değişkenlerin durağan bir yapıda olduklarını söylemek mümkün görünmemektedir. Düzey değerlerinde durağan görünüm sergilemeyen değişkenlerin birinci farkları alınarak durağanlık testi yapılmıştır.

Her üç test için de söz konusu bulgular yukarıda verilen Tablo 5'te gösterilmektedir. Elde edilen bulgulara göre, birinci farkı alınan lnFDI değişkeninin LLC (2003) testinde yer alan sabit artı trend modeli haricinde diğer tüm testlerde durağan olduğu; yani, birim kök içermediği sonucuna ulaşılmıştır. Bu haliyle birinci farkı alınmış lnFDI değişkeni için olasılık değerleri itibariyle boş hipotez olan "seriler birim kök içermektedir" önermesi reddedilmiş ve serilerin birim kök içermediğine dair alternatif hipotez kabul edilmiştir. Modelin açıklayıcı değişkenleri için de fark alma işlemi uygulandığında, aynı şekilde tüm değişkenler için boş hipotezin reddedildiği ve serilerin I(1) düzeyinde durağan görünüm sergiledikleri görülmektedir. 
Tablo 5: Panel Birim Kök Testi Sonuçları (Birinci Fark)

\begin{tabular}{|c|c|c|c|c|c|c|}
\hline \multirow{2}{*}{$\begin{array}{l}\text { Değişkenler } \\
(\Delta)\end{array}$} & \multicolumn{2}{|r|}{ LLC } & \multicolumn{2}{|r|}{ IPS } & \multicolumn{2}{|c|}{ Fisher ADF } \\
\hline & Sabit & Sabit + Trend & Sabit & Sabit + Trend & Sabit & Sabit + Trend \\
\hline$\Delta \operatorname{lnFDI}$ & $\begin{array}{l}-9.91466^{*} \\
(0.0000)\end{array}$ & $\begin{array}{l}-0.71245 \\
(0.2381)\end{array}$ & $\begin{array}{l}-11.7568^{*} \\
(0.0000)\end{array}$ & $\begin{array}{l}-6.58103^{*} \\
(0.0000)\end{array}$ & $\begin{array}{l}113.427^{*} \\
(0.0000)\end{array}$ & $\begin{array}{l}57.5891^{*} \\
(0.0000)\end{array}$ \\
\hline$\Delta \ln H C$ & $\begin{array}{l}-3.60150^{*} \\
(0.0002)\end{array}$ & $\begin{array}{l}-4.99739^{*} \\
(0.0000)\end{array}$ & $\begin{array}{l}-3.75534^{*} \\
(0.0001)\end{array}$ & $\begin{array}{l}-3.60198^{*} \\
(0.0002)\end{array}$ & $\begin{array}{l}38.8433^{*} \\
(0.0001)\end{array}$ & $\begin{array}{l}33.5955^{*} \\
(0.0008)\end{array}$ \\
\hline$\Delta \operatorname{lnGDP}$ & $\begin{array}{l}-5.00087^{*} \\
(0.0000)\end{array}$ & $\begin{array}{l}-4.42802^{*} \\
(0.0000)\end{array}$ & $\begin{array}{l}-5.16080^{*} \\
(0.0000)\end{array}$ & $\begin{array}{l}-3.63482^{*} \\
(0.0001)\end{array}$ & $\begin{array}{l}48.5171 * \\
(0.0000)\end{array}$ & $\begin{array}{l}34.0401 * \\
(0.0007)\end{array}$ \\
\hline$\triangle \operatorname{lnOPEN}$ & $\begin{array}{l}-6.95613^{*} \\
(0.0000)\end{array}$ & $\begin{array}{l}-4.68715^{*} \\
(0.0000)\end{array}$ & $\begin{array}{l}-7.14403^{*} \\
(0.0000)\end{array}$ & $\begin{array}{l}-5.54546^{*} \\
(0.0000)\end{array}$ & $\begin{array}{l}67.5957 * \\
(0.0000)\end{array}$ & $\begin{array}{l}49.1991 * \\
(0.0000)\end{array}$ \\
\hline$\Delta \ln N R$ & $\begin{array}{l}-10.7967^{*} \\
(0.0000)\end{array}$ & $\begin{array}{l}-7.95783^{*} \\
(0.0000)\end{array}$ & $\begin{array}{l}-9.51006^{*} \\
(0.0000)\end{array}$ & $\begin{array}{l}-8.58907^{*} \\
(0.0000)\end{array}$ & $\begin{array}{l}91.3415^{*} \\
(0.0000)\end{array}$ & $\begin{array}{l}75.4655^{*} \\
(0.0000)\end{array}$ \\
\hline$\Delta \operatorname{lnINF}$ & $\begin{array}{l}-8.80553^{*} \\
(0.0000)\end{array}$ & $\begin{array}{l}-6.91061^{*} \\
(0.0000)\end{array}$ & $\begin{array}{l}-8.29370^{*} \\
(0.0000)\end{array}$ & $\begin{array}{l}-7.88893^{*} \\
(0.0000)\end{array}$ & $\begin{array}{l}79.1171 * \\
(0.0000)\end{array}$ & $\begin{array}{l}69.2488^{*} \\
(0.0000)\end{array}$ \\
\hline
\end{tabular}

Notlar: Parantez içinde verilen değerler olasılık değerlerini göstermektedir. * \%1 anlam düzeyini ifade etmektedir. Gecikme uzunlukları Schwarz bilgi kriteri yardımıyla belirlenmiștir.

\subsection{Eşbütünleşme Testi Bulguları}

Modelde yer alan tüm değişkenlerin I(1) sürecini izliyor olması, değişkenler arasında uzun dönemli bir denge ilişkisi, diğer bir ifadeyle eşbütünleşme olabileceği şüphesini doğurmaktadır. Bağımlı değişken olan lnFDI, hem CADF testinde hem de birinci nesil birim kök testlerinde I(1)'de durağanlık gösterdiği için Westerlund (2008) panel eşbütünleşme testi uygulanmaktadır. Durbin-H panel eşbütünleşme testi olarak da bilinen ve yatay kesit bağımlılığını da dikkate alan teknikle elde edilen bulgular Tablo 6'da yer almaktadır.

Tablo 6: Westerlund (2008) Eşbütünleşme Testi

\begin{tabular}{|c|c|c|}
\hline & Test İstatistiği & Olasılık Değeri \\
\hline $\mathrm{DH}_{\mathrm{g}}$ & -0.570 & 0.716 \\
\hline $\mathrm{DH}_{\mathrm{p}}$ & 1.369 & 0.086 \\
\hline
\end{tabular}

Durbin-H eşbütünleşme testi sonuçlarına göre grup istatistiklerinden elde edilen $\left(\mathrm{DH}_{\mathrm{g}}\right)$ bulgular, boş hipotezin kabul edildiğini, diğer bir ifadeyle eşbütünleşme ilişkisinin olmadığını ortaya koymaktadır. Diğer yandan panel istatistikleri $\left(\mathrm{DH}_{\mathrm{p}}\right) \quad \% 10$ anlam düzeyinde bir eşbütünleşme ilişkisinin olabileceğini göstermektedir.
Çalışmada zayıf bir eşbütünleşme ilişkisi gösteren Durbin-H testi bulgularını desteklemek amaciyla Pedroni (1999) ve Kao (1999) tarafından ileri sürülen eşbütünleşme testlerine ait bulgulara yer verilmektedir. $\mathrm{Bu}$ testlere ait boș hipotez "eşbütünleşme yoktur" şeklindedir. Alternatif hipotez ise "tüm birimler eşbütünleşiktir" olarak ifade edilmektedir.

Tablo 7'de verilen Pedroni Eşbütünleşme testi sonuçlarına göre, boş hipotezi ifade eden eş bütünleşme yoktur önermesi p-olasılık değerleri itibariyle reddedilmiştir. Panel istatistiklerinden iki tanesi \%5 seviyesinde, diğer ikisi ise \%1 seviyesinde istatistiksel olarak anlamlı sonuçlar vermiştir. Grup istatistiklerinden ise, iki istatistik için \%1 seviyesinde anlamlı bulgular elde edilmiştir.

Bu durumda modelde yer alan değişkenler için uzun dönemli denge ilişkisinin olduğuna dair alternatif hipotez kabul edilmiştir. Dolayısıyla bağımlı değişken lnFDI ile açıklayıcı değişkenlerin eş bütünleşik olduğu, ele alınan serilerin uzun dönemde birlikte hareket ettiği ve denge ilişkisine sahip olduğu söylenebilir. Değişkenler arasındaki uzun dönemli ilişki Kao (1999) tarafından ileri sürülen eş bütünleşme testi ile de sınanmıştır. Kao eş bütünleşme testi 


\section{B. ÇAYIR, E. ERDEM}

sonuçlarına göre de boş hipotez olan eşbütünleşme yoktur önermesi p-olasılık değeri itibariyle güçlü bir şekilde reddedilmiştir. Dolayısıyla hem Pedroni hem

Tablo 7: Panel Eşbütünleşme Test Sonuçları de Kao eşbütünleşme testi sonuçlarına göre, değişkenler arasında uzun dönemli denge ilişkisinin olduğu belirlenmiştir.

\begin{tabular}{|c|c|c|c|c|}
\hline \multicolumn{5}{|c|}{ Pedroni Panel Eşbütünleşme Testi Sonucu } \\
\hline \multicolumn{5}{|l|}{ (Boyut İçinde) } \\
\hline & t-istatistiği & Olasılık & $\begin{array}{l}\text { Ağırlıklandırılmış } \\
\text { t-istatistiği }\end{array}$ & Olasılık \\
\hline Panel v- (Değișirlik Oranı) & $1-773444^{* *}$ & 0.0381 & 0.591555 & 0.2771 \\
\hline Panel P- (Phillips-Peron Tipi p) & $-1.770151^{* *}$ & 0.0384 & -0.288040 & 0.3867 \\
\hline Panel PP- (Phillips-Peron Tipi t) & $-7.202668^{* * *}$ & 0.0000 & $-3.094874^{* * *}$ & 0.0010 \\
\hline Panel ADF (Dickey-Fuller Tipi t) & $-7.202668^{* * *}$ & 0.0000 & $-3.470062^{* * *}$ & 0.0010 \\
\hline \multicolumn{5}{|l|}{ (Boyut Arasında) } \\
\hline & t- istatistiği & Olasılık & & \\
\hline Grup p- (Phillips-Peron Tipi p) & 0.464642 & 0.6789 & & \\
\hline Grup PP- (Phillips-Peron Tipi t & $-4.271137^{* * *}$ & 0.0000 & & \\
\hline Grup ADF- (Dickey Fuller Tipi t) & $-5.031627^{* * *}$ & 0.0000 & & \\
\hline \multicolumn{5}{|c|}{ Kao Panel Eşbütünleşme Testi Sonucu } \\
\hline & t-istatistiği & & Olasılık & \\
\hline $\mathrm{ADF}$ & $-9.04391^{* * *}$ & & 0.0000 & \\
\hline Kalıntı Varyansı & 0.728107 & & & \\
\hline HAC Varyansı & 0.421751 & & & \\
\hline
\end{tabular}

Not: ${ }^{*}, * * * *$ ifadeleri sırasıyla $\% 10, \% 5$ ve $\% 1$ anlam düzeyini ifade etmektedir.

\subsection{Panel FMOLS ve DOLS Tahminci Sonuçları}

Net DYY girişleri üzerinde belirleyici etkisi olduğu düşünülen açıklayıcı değişkenlere ait katsayılar ve anlamlılık değerleri öncelikle FMOLS tahmincisi aracilığıyla test edilmiştir. FMOLS tahmincisi seriler arasındaki korelasyonu ve içsellik problemlerini hesaba katması sebebiyle geleneksel OLS tahmincisine tercih edilmektedir. FMOLS tahmincisi ayrıca ülkeye özgü sabit etkilerin tahmin edilmesinde heterojenliğe izin vermesi bakımından da öne çıkmaktadır (Khachoo ve Khan, 2012). Tablo 8' de panelin geneli ve BRICS-T ülkeleri için ayrı ayrı katsayılara yer verilmektedir.

Panelin geneline ait sonuçlara bakıldığında, BRICS-T ülkeleri için beşerî sermaye düzeyinin DYY girişlerini \%99 güven düzeyinde pozitif yönde etkilediği sonucuna ulaşılmıștır. $\mathrm{Bu}$ durumda FMOLS tahminci sonuçlarına göre BRICS-T ülkelerinde Lucas paradoksunun geçerli olduğunu söylemek mümkündür. Elde edilen bu sonucun Lucas paradoksu çerçevesinde Noorbakhs vd. (2001), Bal vd. (2014), Cleeve vd. (2015), Kumari ve Sharma (2017) ve Zhuang (2017) gibi iktisatçların elde ettiği bulgularla uyumlu olduğu görülmektedir. Ancak piyasa büyüklügünü gösteren değişkenin beklentilerin aksine DYY girişlerini negatif yönde etkilediği gözlemlenmiştir. Öte yandan doğal kaynak zenginliği ve ticari açıklık değişkenleri beklentilerle uyumlu olarak DYY girişlerini pozitif yönde ve anlaml bir şekilde etkilemektedir. Son olarak enflasyon oranı da beklenildiği üzere panelin genelinde DYY girişleri üzerinde olumsuz ve anlamlı bir etkiye sahiptir. 
Tablo 8: Panel FMOLS Tahminci Sonuçları

\begin{tabular}{|c|c|c|c|c|c|}
\hline Ülkeler & LHC & LGDP & LOPEN & LNR & LINF \\
\hline Brezilya & $\begin{array}{l}3.31^{* *} \\
(2.28)\end{array}$ & $\begin{array}{l}0.28^{* * *} \\
(3.20)\end{array}$ & $\begin{array}{l}0.15 \\
(0.43)\end{array}$ & $\begin{array}{l}-0.30 \\
(-1.34)\end{array}$ & $\begin{array}{l}-0.27^{* * *} \\
(-5.76)\end{array}$ \\
\hline Rusya & $\begin{array}{l}-3.54 \\
(-0.75)\end{array}$ & $\begin{array}{l}0.17 \\
(0.61)\end{array}$ & $\begin{array}{l}-0.80 \\
(-0.71)\end{array}$ & $\begin{array}{l}0.72 \\
(1.66)\end{array}$ & $\begin{array}{l}-0.42^{*} \\
(-2.00)\end{array}$ \\
\hline Hindistan & $\begin{array}{l}3.45^{* * *} \\
(3.67)\end{array}$ & $\begin{array}{l}0.31 \\
(0.70)\end{array}$ & $\begin{array}{l}-0.25 \\
(-0.23)\end{array}$ & $\begin{array}{l}0.71 \\
(1.47)\end{array}$ & $\begin{array}{l}0.02 \\
(0.14)\end{array}$ \\
\hline Çin & $\begin{array}{l}-2.00^{* * *} \\
(-7.78)\end{array}$ & $\begin{array}{l}-0.13^{* *} \\
(-2.55)\end{array}$ & $\begin{array}{l}0.35^{*} \\
(2.05)\end{array}$ & $\begin{array}{l}0.22^{* * *} \\
(3.22)\end{array}$ & $\begin{array}{l}0.03 \\
(1.43)\end{array}$ \\
\hline Güney Afrika & $\begin{array}{l}-5.26 \\
(-1.65)\end{array}$ & $\begin{array}{l}-2.20^{* * *} \\
(-3.38)\end{array}$ & $\begin{array}{l}4.63^{* *} \\
(2.54)\end{array}$ & $\begin{array}{l}0.58 \\
(1.29)\end{array}$ & $\begin{array}{l}0.38 \\
(1.46)\end{array}$ \\
\hline Türkiye & $\begin{array}{l}1.34 \\
(0.49)\end{array}$ & $\begin{array}{l}-2.36^{* * *} \\
(-5.06)\end{array}$ & $\begin{array}{l}7.52^{* * *} \\
(5.22)\end{array}$ & $\begin{array}{l}0.30 \\
(0.87)\end{array}$ & $\begin{array}{l}-0.29 \\
(-1.15)\end{array}$ \\
\hline Panel & $\begin{array}{l}1.71^{* * *} \\
(143.41)\end{array}$ & $\begin{array}{l}-0.58^{* * *} \\
(-35.62)\end{array}$ & $\begin{array}{l}0.34^{* * *} \\
(6.51)\end{array}$ & $\begin{array}{l}1.06^{* * *} \\
(34.76)\end{array}$ & $\begin{array}{l}-0.16^{* * *} \\
(-3.30)\end{array}$ \\
\hline
\end{tabular}

Notlar: ${ }^{*}, * * * *$ ifadeleri sırasıyla $\% 10, \% 5$ ve $\% 1$ anlam düzeyini ifade etmektedir. Parantez içindeki değerler t istatistiklerini göstermektedir. Modelde sabit ve trend spesifikasyonuna yer verilmemiştir.

Panel FMOLS sonuçları ülke bazında değerlendirildiğinde, beşerî sermaye düzeyinin DYY girişlerini pozitif yönde etkileyeceği hipotezi, Brezilya ve Hindistan için pozitif katsayılar ve olasılık değerleri itibariyle geçerli görünmektedir. Öte yandan, Çin özelinde beşerî sermaye düzeyinin DYY girişlerini negatif yönde etkilediğine dair katsayı istatistiksel olarak anlamlıdır. $\mathrm{Bu}$ sonuç, Çin'e yönelik DYY girişlerinde ucuz işgücü maliyetleri beklentisinin geçerli olduğu yaklaşımını desteklemektedir. Türkiye, Rusya ve Güney Afrika için beşerî sermaye düzeyi ile DYY girişleri arasında istatistiksel olarak anlamlı bir ilişkiye rastlanmamıştır.

Diğer taraftan Kao ve Chiang (2001) tarafından geliştirilen panel DOLS tekniğine göre, uzun dönem kovaryansların birimlere göre homojen olduğu varsayılmaktadır. Farkı alınan seriler için gecikme uzunluğu ve öncül değeri belirlenmektedir. Panel DOLS tahminci sonuçlarının hesaplanmasında öncül ve gecikmeli değerlerin kullanılmasının tahminci sapmalarını azalttığı belirtilmektedir. Ayrıca panel DOLS tahmincisi ve $\mathrm{t}$ istatistiklerinin homojen ve heterojen panellerin tümünde başarılı performans sergiledikleri Monte Carlo simülasyon sonuçlarıyla kanıtlanmıştır
(Tatoğlu, 2017: 213). Panel DOLS tahminci sonuçları Tablo 9 itibariyle gösterilmektedir.

DOLS tahminci sonuçlarına göre, Panelin geneli için elde edilen bulgular Lucas paradoksunu destekler niteliktedir. Beşerî sermaye düzeyi ile DYY girişleri arasında pozitif yönlü ve anlamlı bir ilişkinin olduğu gözlemlenmiştir. Öyle ki, beşerî sermaye düzeyinde gerçekleşen \%1'lik bir artış BRICS$\mathrm{T}$ ülkelerine yönelen DYY girişlerini \%1.04 düzeyinde artırmaktadır. Piyasa büyüklüğü ve ticari açıklık ile DYY girişleri arasında pozitif yönlü bir ilişki olmakla beraber, bu sonuçlar istatistiksel olarak anlamlı değildir. Öte yandan, BRICS-T ülkelerinde doğal kaynak zenginliğinin DYY girişleri üzerinde olumlu yönde bir etkisinin olduğu görülmektedir. Son olarak enflasyon oranı ise ele alınan ülkeler için beklendiği üzere DYY girişlerini olumsuz yönde etkilemektedir.

Ülke bazında bulgulara göre, Türkiye için beşerî sermaye faktörü ile DYY girişleri arasında pozitif yönlü ilişki görülmekle birlikte, bu ilişki istatistiksel olarak anlaml değildir. Çin'e dair elde edilen bulgular FMOLS tahminci sonuçları ile uyumlu olarak, beşerî sermaye faktörünün DYY girişlerini negatif yönde etkilediğini göstermektedir. 


\section{B. CAYIR, E. ERDEM}

Hindistan'da ise, beșerî sermaye düzeyinin FMOLS tahmincisinde olduğu gibi DOLS tahmincisinde de DYY girișlerini pozitif yönde ve anlamlı biçimde etkilediği görülmektedir. Son olarak, Panel DOLS sonuçlarına göre,
Brezilya, Rusya ve Güney Afrika özelinde beșerî sermaye faktörü DYY girişleri üzerinde istatistiksel olarak anlaml bir etkiye sahip değildir.

Tablo 9: Panel DOLS Tahminci Sonuçları

\begin{tabular}{|c|c|c|c|c|c|}
\hline Ülkeler & LHC & LGDP & LOPEN & LNR & LINF \\
\hline Brezilya & $\begin{array}{l}4.22 \\
(1.69)\end{array}$ & $\begin{array}{l}0.27^{*} \\
(1.77)\end{array}$ & $\begin{array}{l}0.42 \\
(0.66)\end{array}$ & $\begin{array}{l}-0.40 \\
(-1.04)\end{array}$ & $\begin{array}{l}-0.31^{* * *} \\
(-4.45)\end{array}$ \\
\hline Rusya & $\begin{array}{l}-0.74 \\
(-0.17)\end{array}$ & $\begin{array}{l}-0.01 \\
(-0.03)\end{array}$ & $\begin{array}{l}0.15 \\
(0.13)\end{array}$ & $\begin{array}{l}0.41 \\
(0.92)\end{array}$ & $\begin{array}{l}-0.45^{* *} \\
(-2.66)\end{array}$ \\
\hline Hindistan & $\begin{array}{l}3.70^{* * *} \\
(2.96)\end{array}$ & $\begin{array}{l}0.32 \\
(0.55)\end{array}$ & $\begin{array}{l}-0.23 \\
(-0.17)\end{array}$ & $\begin{array}{l}0.68 \\
(1.09)\end{array}$ & $\begin{array}{l}0.05 \\
(0.24)\end{array}$ \\
\hline Çin & $\begin{array}{l}-2.10^{* * *} \\
(-6.56)\end{array}$ & $\begin{array}{l}-0.12^{*} \\
(-1.80)\end{array}$ & $\begin{array}{l}0.32 \\
(1.46)\end{array}$ & $\begin{array}{l}0.20^{* *} \\
(2.25)\end{array}$ & $\begin{array}{l}0.03 \\
(1.09)\end{array}$ \\
\hline Güney Afrika & $\begin{array}{l}-2.60 \\
(-0.51)\end{array}$ & $\begin{array}{l}-2.70^{* *} \\
(-2.74)\end{array}$ & $\begin{array}{l}6.56^{* *} \\
(2.41)\end{array}$ & $\begin{array}{l}0.35 \\
(0.48)\end{array}$ & $\begin{array}{l}0.04 \\
(0.12)\end{array}$ \\
\hline Türkiye & $\begin{array}{l}3.13 \\
(0.66)\end{array}$ & $\begin{array}{l}-2.18^{* * *} \\
(-3.69)\end{array}$ & $\begin{array}{l}7.07^{* * *} \\
(4.02)\end{array}$ & $\begin{array}{l}0.30 \\
(0.50)\end{array}$ & $\begin{array}{l}-0.14 \\
(-0.32)\end{array}$ \\
\hline Panel & $\begin{array}{l}1.04^{*} \\
(1.91)\end{array}$ & $\begin{array}{l}0.03 \\
(0.33)\end{array}$ & $\begin{array}{l}0.21 \\
(0.81)\end{array}$ & $\begin{array}{l}0.43^{* * *} \\
(2.88)\end{array}$ & $\begin{array}{l}-0.14^{*} \\
(-1.70)\end{array}$ \\
\hline
\end{tabular}

Notlar: ${ }^{*},{ }^{* *}{ }^{* * *}$ ifadeleri sırasıyla $\% 10, \% 5$ ve $\% 1$ anlam düzeyini ifade etmektedir. Parantez içindeki değerler t istatistiklerini göstermektedir. Modelde sabit ve trend spesifikasyonuna yer verilmemiștir.

Çalışmanın temel hipotezini ortaya koyan beşeri sermaye DYY ilişkisine dair elde edilen bulguların ilgili literatürle klyaslanmasında fayda görülmektedir. Literatür incelemesinde vurgulandığı üzere söz konusu ilişkiye dair bulgular 1980 öncesi ve sonrası dönem için yapılan analizler itibariyle farklılaşmaktadır. 1980 sonrası dönem için yapılan analizlerle uyumlu olarak bu çalışmada da beșeri sermaye düzeyi ile DYY girişleri arasında pozitif yönlü ilişkinin varlığını destekleyen bulgulara ulaşılmıştır (Noorbakhs vd. (2001), Checchi vd. (2007), Suliman ve Mollick (2009), Bal vd. (2014), Cleeve vd. (2015), Kumari ve Sharma (2017) ve Zhuang (2017)). Ancak Karagöz (2007) tarafından Türkiye üzerine ve Mina (2007) tarafından Körfez İşbirliği Ülkeleri üzerine elde edilen bulgular literatürdeki genel eğilimden farklı olarak negatif yönlü ilişkiyi işaret etmektedir.

\section{SONUÇ VE DEĞERLENDİRME}

$\mathrm{Bu}$ çalışmada Lucas (1990) tarafından ileri sürülen ve literatürde Lucas paradoksu olarak bilinen bir yaklaşımdan hareketle, BRICS-T ülkeleri için beşerî sermaye faktörünün DYY girişleri üzerindeki etkisinin analiz edilmesi hedeflenmiştir. 1993-2017 dönemine ait yıllık verilerden yararlanılarak, panel veri yöntemi dahilinde panel birim kök testleri, eşbütünleşme testleri ve FMOLS-DOLS tahmincileri kullanılmıștır. Literatürde DYY girişlerinin belirleyicileri olarak sıklıkla müracaat edilen ticarete açıklık düzeyi, piyasa büyüklüğü, doğal kaynak zenginliği ve enflasyon oranı da oluşturulan ekonometrik modele dahil edilmiştir.

Yapılan birim kök testleri sonucunda tüm değişkenlerin birinci fark düzeyinde durağan hale geldiği gözlemlenmiştir. Eşbütünleşme test sonuçları ise, değişkenler arasında uzun dönemli ilişkinin varlığını teyit etmiştir. Çalışmada kullanılan Panel FMOLS ve DOLS tahminci sonuçlarına göre, beşerî sermaye düzeyinin DYY girişlerini pozitif ve anlamlı bir şekilde etkilediği görülmüştür. Panel DOLS tahminci sonuçlarına göre, beşerî sermaye düzeyinde gerçekleşen \%1'lik artışın, uzun 
dönemde DYY girișlerini așağı yukarı kendisi kadar (\%1.04) artırdığı sonucuna ulaşılmıştır. Elde edilen bu sonuç, son dönemde gerçekleştirilen analizlerle de uyumlu olarak beşerî sermaye faktörünün, DYY girişlerinin önemli bir belirleyicisi olduğu önermesini desteklemektedir. $\mathrm{Bu}$ sonuçtan hareketle, BRICS-T paneli için Lucas paradoksunun çok güçlü olmasa da geçerli olduğu söylenebilir. Ancak, analizde yer alan diğer açılkayıcı değişkenler arasında piyasa büyüklügü ve ticari açıklık düzeyi, BRICS-T ülkeleri için anlamlı sonuçlar vermemiștir. Öte yandan, beklentilerle uyumlu olarak doğal kaynak zenginliğinin DYY girișlerini olumlu yönde, enflasyon oranının ise olumsuz yönde etkilediği sonucuna ulaşılmıștır.

Ülke bazında tahmin sonuçlarına bakıldığında; Brezilya ve Hindistan için beşerî sermaye düzeyi ile DYY girișleri arasında pozitif yönlü ve anlamlı bir ilişki olduğunu anlaşılmaktadır. Türkiye özelinde ise, DYY girişleri ile beșerî sermaye arasında doğru yönlü bir ilişki görülmekle beraber, istatistiksel olarak anlamlı sonuç elde edilememiştir Öte yandan, Çin için beșerî sermaye düzeyinin DYY girişlerini olumsuz etkilediği sonucuna ulaşılmıştır. Söz konusu ters yönlü ilişki, Çin'e yönelen yabancı yatırımların nitelikli işgücünden ziyade ucuz işgücü beklentisi içerisinde olduğu şeklinde yorumlanabilir. Son olarak Güney Afrika için beșerî sermaye ile DYY girişleri arasında istatistiksel olarak anlamlı bir ilişski çıkmamıştır.

Sonuç itibariyle, panelin geneli için elde edilen bulgular beșerî sermaye düzeyinin güçlü bir DYY belirleyicisi olduğunu ortaya koymaktadır. Ancak Rusya, Güney Afrika ve Türkiye üçlüsü için DYY girişleri ile beșerî sermaye arasında anlamlı ilişkinin elde edilememesi bu ülkeler için daha kapsamlı analiz ve incelemelere gerek olduğu kanısını güçlendirmektedir. Birbirinden oldukça farklı yapısal özelliklere sahip bu üç ülke için iç ve dış siyasi etkenlerin, hukukun üstünlüğünün, mülkiyet hakkının ve teșebbüs hürriyetinin göz önünde bulundurulduğu daha kapsamlı bir araștırmanın yapılması, daha sağlıklı sonuç almaya yardımcı olacaktır. Ayrıca, söz konusu ülkeler için bölge veya şehir bazında mekânsal ekonometrik tekniklerin kullanılarak beșerî sermaye DYY ilişkisinin ortaya konulması ilgili literatüre önemli katkılar sunabilecektir. Öte yandan ev sahibi ülkelere giriş yapan DYY'nin sektörler bazında incelenerek, ele alınan sektörlerde beșerî sermaye düzeyi ile giriş yapan DYY miktarı arasındaki ilişkinin ortaya konması özgün katkıları beraberinde getirebilecektir. $\mathrm{Bu}$ analizler sayesinde beșerî sermaye ve DYY ilișkisini daha kapsaml bir biçimde açıklayabilecek çalışmaların ortaya çlkabileceği düşünülmektedir.

\section{REFERENSLAR}

BAL, H., ALGAN, N., DEMIRAL, M. (2014). Gelişmekte olan Ülkeler Küresel Sermayeyi Çekme Konusunda Niçin Başarısız Olmaktadırlar? Balkan Ülkeleri İçin Lucas Paradoksunun Yeniden İncelenmesi. International Conference on Euroasian Economies 2014.

BECKER, G. S. (1994). Human Capital: A Theoretical and Empirical Analysis with Special Reference to Education, The University of Chicago Press, 15-28.
BREUSCH, T.S., PAGAN, A.R. (1980). The Langrange Multiplier Test and its Applications to Model Specification in Econometrics, Rev. Econ. Stud., 47, 239-253.

CHECCHI, D., DE SIMMONE, G., FAINI, R. (2007). Skilled Migration, FDI and Human Capital Investment. IZA Discussion Paper, No.2795.

CLEEVE E.A., DEBRAH, Y., YIHESIS, Z. (2015). Human Capital and FDI Inflow: An Assessment of the African Case, World Development, 74, 114. 
COLEMAN, J. S. (1988). Social Capital in the Creation of Human Capital. The American Journal of Sociology, 94, 95-120.

COUGHLIN, C. C., SEGEV, E. (2000). Foreign Direct Investment in China: A Spatial Econometric Study. Blackwell Publishers.

DUNNING, J. H., DILYARD, J.R. (1999). Towards a General Paradigm of Foreign Direct and Foreign Portfolio Investment. Transnational Cooperations, 8(1).

HANSON, J.R. (1996). Human Capital and Direct Investment in Poor Countries. Explorations in Economic History, 33(1), 86106.

IM, K.S., PESERAN, M.H., SHIN, Y. (2003). Testing For Unit Roots in Heterogeneous Panels. Journal of Econometrics, 115(1), 53-74.

JOHNSON, A. (2006). The Effects of FDI Inflows on Host Country Economic Growth. CESIS Electronic Working Paper Series, Paper No. 58.

KHACHOO, A.Q., KHAN, M.I. (2012). Determinants of FDI Inflows to Developing Countries: A Panel Data Analysis. Munich Personal Repec Archive, Paper No.37278.

KARAGÖZ, K. (2007). Türkiye'de Doğrudan Yabancl Yatırım Girişlerini Belirleyen Faktörler. Journal of Yasar University, 8(2), 927-948.

KASTRATI, S. (2013). The Effects of Foreign Direct Investment for Host Country's Economy. European Journal of Interdisciplinary Studies, 5(1).

KUMARI, R., SHARMA, A.K. (2017). Determinants of Foreign Direct Investment in Developing Countries: A Panel Data Study. International Journal of Emerging Markets, 12(4), 658-682.

LEVIN, A., LIN, C.F., CHU, C.S.J. (2002). Unit Root Tests in Panel Data: Asymptotic and Finite-Sample Properties. Journal of Econometrics, 108(1), 1-24.

LIPSEY, R.E., SJOHOLM, F. (2005). The Impact of Inward FDI on Host Countries: Why Such Different Answers. Institute for International
Economics Center for Global Development, 2343.

LUCAS, R. E. Jr. (1990). Why Doesn't Capital Flow from Rich to Poor Countries? The American Economic Review, 80(2), 92-96.

MADDALA, G.S., WU, S. (1999). A Comparative Study of Unit Root Tests with Panel Data and a New Simple Test. Oxford Bulletin of Economics and Statistics, Special Issue.

MAJEED, M.T., AHMAD, E. (2008). Human Capital Development and FDI in Developing Countries. Munich Personal Repec Archive.

MINA, W. (2007). The Location Determinants of FDI in the GCC Countries. Journal of Multinational Financial Management, No.17, 336-348.

MIYAMOTO, K. (2003). Human Capital Formation and Foreign Direct Investment in Developing Countries. OECD Development Centre, Working Paper No. 211.

NARULA, R. (1996). Multinational Investment and Economic Structure: Globalization and Competitiveness, London: Routledge, https://doi.org/10.4324/9780203011362

NOORBAKSH F., PALONI, A., YOUSSEF, A. (2001). Human Capital and FDI Inflows to Developing Countries: New Empirical Evidence. World Development, 29(9), 15931610.

NUNNENKAMP, P. (2002). Determinants of FDI in developing countries: has globalization changed the rules of the game? Kiel Working Paper, No.1122.

PESERAN, H.M. (2004). General Diagnostic Tests for Cross Section Dependence in Panels. Working Paper, No: 0435, University of Cambiridge.

PESERAN H.M. (2006). Estimation and Inference in Large Heterogeneous Panels with a Multifactor Error Structure. Econometrica, 74(4), 967-1012.

PESERAN, M.H. (2007). A Simple Panel Unit Root Test in the Presence of Cross-Section 
Dependence. Journal of Applied Econometrics, 22, 265-312.

PESERAN, M.H., ULLAH, A., YAMAGATA, T. (2008). A Bias-Adjusted LM Test of Error Crosssection Independence. The Econometrics Journal, 11(1), 105-127.

PESERAN, M.H., YAMAGATA, T. (2008). Testing Slope Homogeneity in large panels. Journal of Econometrics, 142(1), 50-93.

ROOT, F.R., AHMED, A. (1979). Empirical Determinants of Manufacturing Direct Foreign Investment in Developing Countries Economic Development and Cultural Change, 27, No.24.

SCHNEIDER, F., FREY, B. (1985). Economic and Political Determinants of Foreign Direct Investment. World Development, 13(2).

SCHULTZ, T. W. (1961). Investment in Human Capital. The American Economic Review, 51(1), 1-17.
SULIMAN, A. H. MOLLICK, A.V. (2009). Human Capital Development, War and FDI in SubSaharan Africa. Oxford Development Studies.

TATOĞLU, F. Y. (2017). Panel Zaman Serileri Analizi, Beta Basım Yayım Dağıtım A.Ş, 1. Baskı, İstanbul.

UNCTAD, (2018). World Investment Report.

UNDP. (2016). Human Development Report 2016.

UNDP. (2018). Human Development Indices and Indicators: 2018 Statistical Update.

WESTERLUND, J. (2008). Panel Cointegration Tests of the Fisher Effect. Journal of Applied Econometrics, 23, 193-233.

ZHUANG, H. (2017). The Effect of Foreign Direct Investment on Human Capital Development in East Asia. Journal of The Asia Pacific Economy, 22(2), 195-211. 